\title{
LncRNA PLAC 2 is Downregulated in Osteosarcoma and Regulates Cancer Cell Proliferation Through miR-93 [Erratum]
}

Sun X, Yu L, Shi Y, Guo W. Cancer Manag Res. 2020;12:3623-3629.

The authors have advised that Figure 3 on page 3627 is incorrect. This error was introduced by the Editorial staff during the publication process. The correct Figure 3 is shown below.
A

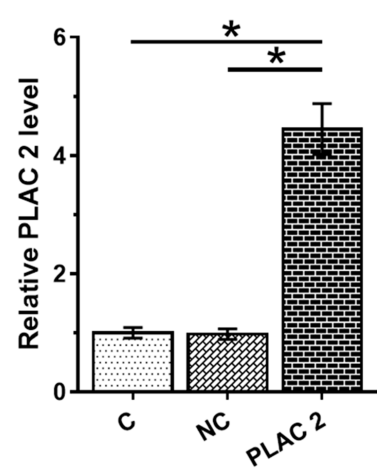

B

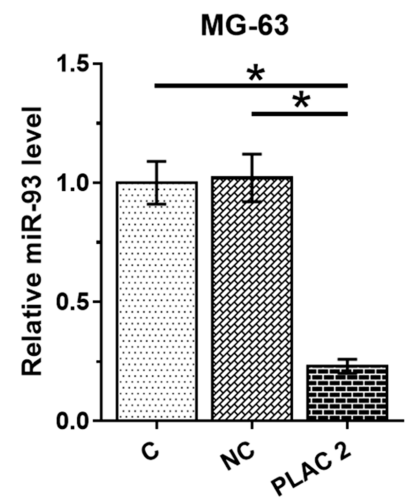

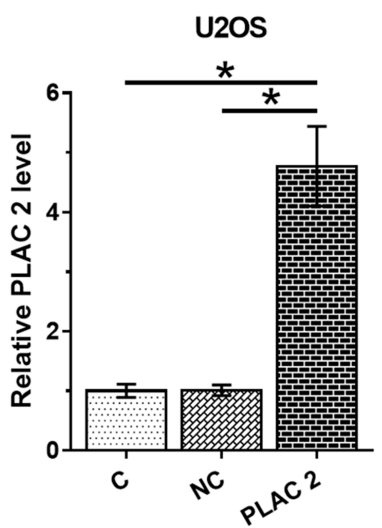

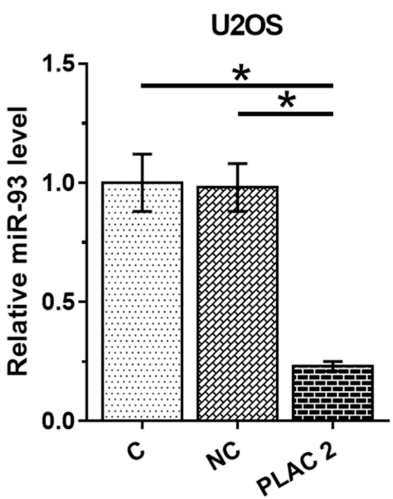

MG-63

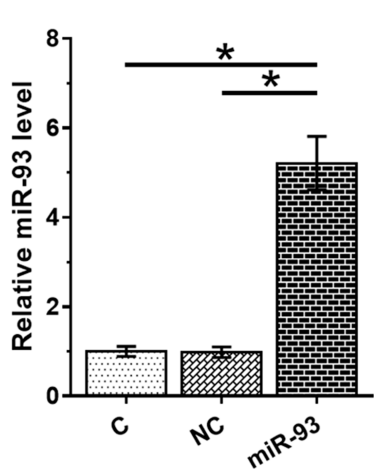

C

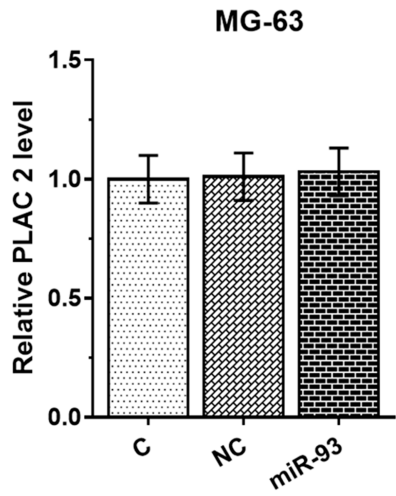

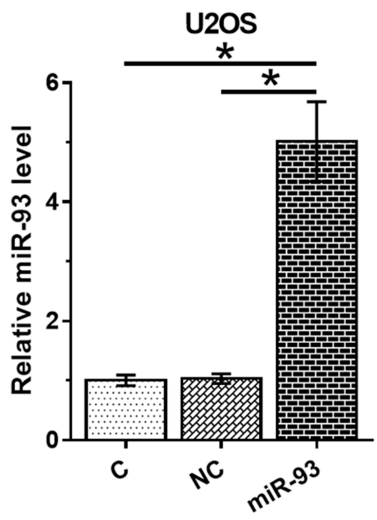

U2OS

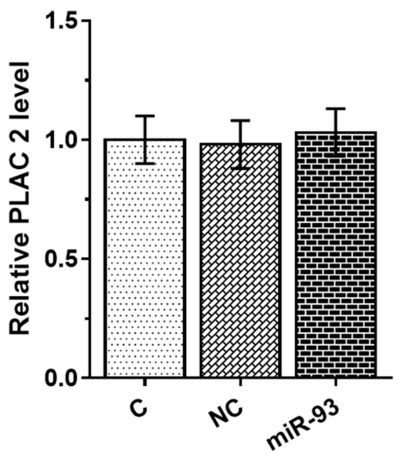

Figure I Overexpression of PLAC 2 led to downregulated miR-93 in MG-63 and U2OS cells. MG-63 and U2OS cells were transfected with miR-93 mimic or PLAC 2 expression vector to analyze the interactions between PLAC 2 and miR-93. Overexpression of PLAC 2 and miR-93 was confirmed at $24 \mathrm{~h}$ post-transfection (A). The effects of overexpression of PLAC 2 on miR-93 (B) and the effects of overexpression of miR-93 on PLAC 2 (C) were also analyzed by qPCR at $24 \mathrm{~h}$ post-transfection. ANOVA (one-way) and Tukey's test were used to compare the mean values from 3 biological replicates (A). C, control cells without transfection; NC, negative control cells transfected with empty vector or NC miRNA; ${ }^{p} p<0.05$.

\section{Publish your work in this journal}

Cancer Management and Research is an international, peer-reviewed open access journal focusing on cancer research and the optimal use of preventative and integrated treatment interventions to achieve improved outcomes, enhanced survival and quality of life for the cancer patient.
The manuscript management system is completely online and includes a very quick and fair peer-review system, which is all easy to use. Visit http://www.dovepress.com/testimonials.php to read real quotes from published authors. 